BIOS : Jurnal Teknologi Informasi dan Rekayasa Komputer

Vol. 1, No. 2, September 2020, hlm. 70 - 79

ISSN: 2722-0850

Laman Jurnal: http://bios.sinergis.org

\title{
Perbandingan Akurasi Metode TOPSIS dan Metode Weight Product untuk Menentukan Siswa Berprestasi
}

\author{
Abdul Fatahillah ${ }^{1}$, Mudafiq Riyan Pratama ${ }^{2}$ \\ ${ }^{1}$ Teknik Informatika, Universitas Muhammadiyah Jember,fatahhillah96@gmail.com \\ ${ }^{2}$ Politeknik Negeri Jember, mudafiq.riyan@polije.ac.id
}

\begin{tabular}{|c|c|}
\hline Keywords: & ABSTRACT \\
\hline $\begin{array}{l}\text { Perbandingan, } \\
\text { Akurasi, } \\
\text { TOPSIS, } \\
\text { Weight Product, } \\
\text { Siswa Berprestasi }\end{array}$ & $\begin{array}{l}\text { Dalam menentukan siswa berprestasi (studi kasus di MTs. Al-Ishlah Jenggawah } \\
\text { Jember) terdapat beberapa kriteria yang menjadi penilaian. Kriteria yang terdapat } \\
\text { pada penilaian siswa berprestasi di MTs. Al-Ishlah meliputi rata-rata rapor, kelakuan, } \\
\text { kedisiplinan, kerapian dan absensi. Demi subjektifitas penilaian maka suatu metode } \\
\text { yang tepat sangat diperlukan, yaitu diantaranya Technique for Others Referencean by } \\
\text { Similarity to Ideal Solution (TOPSIS) dan Weight Product (WP). Tujuan penelitian } \\
\text { ini untuk membandingkan tingkat akurasi metode TOPSIS dan WP, dimana masing- } \\
\text { masing penilaian dalam hal ini adalah semua siswa dibandingkan satu dengan yang } \\
\text { lainnya, sehingga memberikan output nilai intensitas prioritas yang menghasilkan } \\
\text { nilai ranking setiap siswa. Setelah dilakukan perbandingan dan dianalisis, didapatkan } \\
\text { hasil akurasi dari kedua metode, yaitu pada metode TOPSIS adalah } 84 \% \text { sedangkan } \\
\text { pada metode WP didapatkan nilai akurasi } 87,5 \% \text {. Artinya dalam studi kasus } \\
\text { penetuan siswa berprestasi yang dilakukan di MTs. Al-Ishlah Jenggawah Jember } \\
\text { menunjukkan bahwa metode WP lebih baik dibandingkan metode TOPSIS. }\end{array}$ \\
\hline Kata Kunci & ABSTRAK \\
\hline $\begin{array}{l}\text { Comparison, } \\
\text { Accuracy, } \\
\text { TOPSIS, } \\
\text { Weight Product, } \\
\text { Student Achievement }\end{array}$ & $\begin{array}{l}\text { In determining outstanding students (a case study at MTs. Al-Ishlah Jenggawah } \\
\text { Jember) there are several criteria to be assessed. The criteria contained in student } \\
\text { achievement in MTs. Al-Ishlah includes the average report card, behavior, discipline, } \\
\text { neatness and attendance. For the sake of subjective assessment, an appropriate } \\
\text { method is needed, namely the Technique for Others Reference by Similarity to Ideal } \\
\text { Solution (TOPSIS) and Weight Product (WP). The purpose of this study is to } \\
\text { compare the accuracy of TOPSIS and WP, where each assessment in this case is that } \\
\text { all students are compared with one another, thus providing an output of priority } \\
\text { values that produce a rating value for each student. After comparison and analysis, } \\
\text { the accuracy of both methods was obtained, namely the TOPSIS method was } 84 \% \\
\text { while the WP method obtained an accuracy value of } 87.5 \% \text {. This means that in the } \\
\text { case study, the determination of outstanding students is carried out at MTs. Al-Ishlah } \\
\text { Jenggawah Jember showed that the WP method was better than the TOPSIS method. }\end{array}$ \\
\hline
\end{tabular}

\section{Korespondensi Penulis:}

Abdul Fatahillah, Universitas Muhammadiyah Jember, Jember

Telepon : +6282229414949

Email: fatahhillah96@gmail.com

\section{PENDAHULUAN}

Prestasi belajar di bidang pendidikan adalah hasil dari pengukuran terhadap peserta didik yang meliputi faktor kognitif, afektif dan psikomotor setelah mengikuti proses pembelajaran yang diukur dengan menggunakan instrumen tes atau instrumen yang relevan. Prestasi belajar adalah hasil yang dicapai seseorang dalam penguasaan pengetahuan dan keterampilan yang dikembangkan dalam pelajaran, lazimnya ditunjukkan dengan tes angka nilai yang diberikan oleh guru [1]. Sedangkan menurut Harjati (2008), menyatakan bahwa prestasi merupakan hasil usaha yang dilakukan dan menghasilkan perubahan yang dinyatakan dalam bentuk simbol untuk menunjukkan kemampuan pencapaian dalam hasil kerja dalam waktu tertentu [2]. 
Dalam rangka menentukan siswa berprestasi, maka penelitian ini melakukan perbandingan akurasi kinerja metode TOPSIS dan Weighted Product (WP) untuk menghasilkan penentuan pilihan dengan banyak kriteria (multikriteria). Metode Technique for Others Reference by Similarity to Ideal Solution (TOPSIS) merupakan salah satu metode pengambilan keputusan multikriteria yang pertama kali diperkenalkan oleh Yoon dan Hwang tahun 1981, menggunakan prinsip bahwa alternatif yang terpilih harus memiliki jarak terdekat dari solusi ideal positif dan terjauh dari solusi ideal negatif dari sudut pandang geometris dengan menggunakan jarak euclidean untuk menentukan kedekatan relatif dari suatu alternatif dengan solusi optimal. Metode TOPSIS digunakan sebagai suatu upaya untuk menyelesaikan permasalahan multiple criteria decission making. Hal ini disebabkan konsepnya sederhana dan mudah dipahami komputasinya efisien dan memiliki kemampuan untuk mengukur kinerja relatif dari alternatif-alternatif keputusan.

Sedangkan Metode Weighted Product (WP) adalah salah satu metode penyelesaian pada sistem pendukung keputusan. Metode ini mengevaluasi beberapa alternatif terhadap sekumpulan atribuat atau kriteria, dimana setiap atribut saling tidak bergantung satu dengan yang lainnya. Menurut Yoon (dalam buku Kusumadewi, 2006), metode Weighted Product menggunakan teknik perkalian untuk menghubungkan rating atribut, dimana rating tiap atribut harus dipangkatkan terlebih dahulu dengan bobot atribut yang bersangkutan [3]. Metode TOPSIS dan Weight Product ini dapat menentukan nilai bobot untuk setiap atribut, kemudian dilanjutkan dengan proses perankingan yang akan menyeleksi alternatif terbaik dari sejumlah alternatif namun keduanya mempunyai metode perhitungan yang berbeda sehingga akan diketahui perbandingan antara kedua metode dalam menyelesaikan studi kasus pemilihan siswa berprestasi.

Dari uraian diatas menjadi suatu pertimbangan untuk melakukan penelitian yang berjudul "Perbandingan Akurasi Metode TOPSIS Dengan Metode Weight Product Untuk Menentukan Siswa Berprestasi." Kedua metode tersebut dipilih karena menurut penelitian Vyas dan Misal (2013), metode Weighted Product dapat menyelesaikan permasalahan single/multi dimensi dan dapat menggunakan nilai yang sebenarnya dalam menentukan rating dari setiap alternatif pada setiap kriteria, sedangkan metode TOPSIS dianggap cukup intuitif yang didasarkan pada pertimbangan jarak dan solusi ideal [4]. Dengan metode-metode perangkingan ini, diharapkan dapat memperoleh hasil perbandingan yang akurat antara metode Topsis dan metode Weighted Product (WP) dalam menentukan siswa berprestasi.

\section{METODE PENELITIAN}

Tahapan penelitian ini digambarkan pada alur berikut:

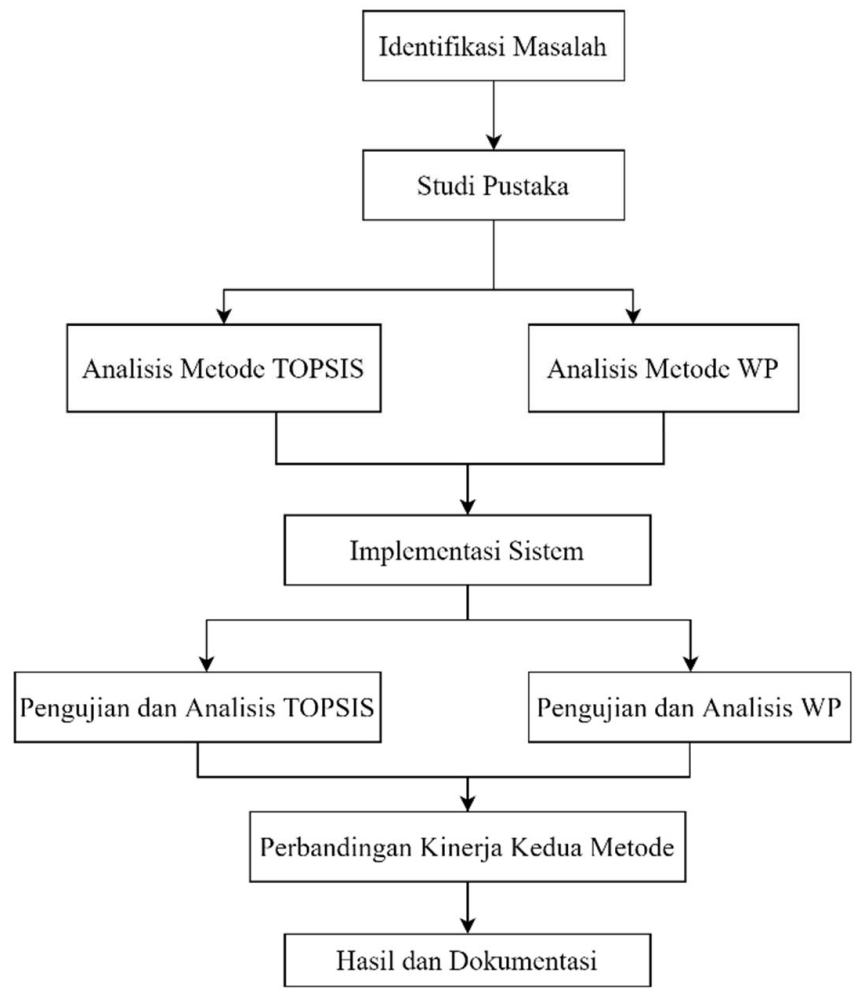

Gambar 1. Tahapan Penelitian

\subsection{Data Penelitian}


Penelitian ini menggunakan beberapa variabel yaitu nilai rata-rata raport, nilai kelakuan, kedisiplinan, kerapian dan nilai kehadiran (absensi). Untuk menjelaskan alur dari metode TOPSIS dan WP ini menggunakan 5 sample data.

Tabel 1. Daftar Siswa Berprestasi MTs Al-Ishlah

\begin{tabular}{|c|c|c|c|c|c|c|c|}
\hline No & NIS & Nama Siswa & Rata-rata Rapor & Kelakuan & kedisiplinan & Kerapian & Absensi \\
\hline 1 & 1834 & ABDUH RAHMAN FAHAT & 78,87 & B & B & C & 3 \\
\hline 2 & 1835 & ABDUL AZIZ & 79,33 & B & A & B & 2 \\
\hline 3 & 1836 & AHMAD FATAHILLAH & 79,27 & B & B & B & 2 \\
\hline 4 & 1837 & AHMAD SAIFULLAH & 79,13 & B & C & B & 1 \\
\hline 5 & 1838 & ERFAN HUDA & 79,2 & C & B & C & 1 \\
\hline
\end{tabular}

Tabel 2. Rubrik Nilai Rata-Rata Rapor

\begin{tabular}{|c|c|c|c|}
\hline Nilai & Grade & Bobot & Keterangan \\
\hline $90-100$ & A & 5 & Sangat Baik \\
\hline $80-89,99$ & B & 4 & Baik \\
\hline $75-79,99$ & C & 3 & Cukup \\
\hline $60-74,99$ & D & 2 & Rendah \\
\hline$<60$ & E & 1 & Sangat Rendah \\
\hline
\end{tabular}

Tabel 3. Rubrik Penilaian Kelakuan Siswa

\begin{tabular}{|c|c|c|}
\hline Kriteria & Bobot & Indikator \\
\hline A (Amat Baik) & 4 & Selalu berkelakuan baik kepada guru dan teman \\
\hline B (Baik) & 3 & Sering berkelakuan baik kepada guru dan teman \\
\hline $\mathrm{C}$ (Cukup) & 2 & $\begin{array}{c}\text { Kadang-kadang berkelakuan baik kepada guru } \\
\text { dan teman }\end{array}$ \\
\hline K (Kurang) & 1 & $\begin{array}{c}\text { Tidak pernah berkelakuan baik kepada guru dan } \\
\text { teman }\end{array}$ \\
\hline
\end{tabular}

Tabel 4. Rubrik Penilaian Kedisiplinan Siswa

\begin{tabular}{|c|c|c|}
\hline Kriteria & Bobot & Indikator \\
\hline A (Amat Baik) & 4 & $\begin{array}{l}\text { Selalu disiplin dalam mengikuti proses } \\
\text { pembelajaran }\end{array}$ \\
\hline B (Baik) & 3 & $\begin{array}{c}\text { Sering disiplin dalam mengikuti proses } \\
\text { pembelajaran }\end{array}$ \\
\hline C (Cukup) & 2 & $\begin{array}{c}\text { Kadang-kadang disiplin dalam mengikuti proses } \\
\text { pembelajaran }\end{array}$ \\
\hline K (Kurang) & 1 & $\begin{array}{c}\text { Tidak pernah disiplin dalam mengikuti proses } \\
\text { pembelajaran }\end{array}$ \\
\hline
\end{tabular}

Tabel 5. Rubrik Penilaian Kerapian Siswa

\begin{tabular}{|c|c|c|}
\hline Kriteria & Bobot & Indikator \\
\hline A (Amat Baik) & 4 & $\begin{array}{c}\text { Selalu berseragam rapi dan menggunakan atribut } \\
\text { yang sesuai peraturan sekolah }\end{array}$ \\
\hline B (Baik) & 3 & $\begin{array}{c}\text { Sering berseragam rapi dan menggunakan atribut } \\
\text { yang sesuai peraturan sekolah }\end{array}$ \\
\hline C (Cukup) & 2 & $\begin{array}{c}\text { Kadang-kadang berseragam rapi dan } \\
\text { menggunakan atribut yang sesuai peraturan } \\
\text { sekolah }\end{array}$ \\
\hline K (Kurang) & 1 & $\begin{array}{c}\text { Tidak pernah berseragam rapi dan menggunakan } \\
\text { atribut yang sesuai peraturan sekolah }\end{array}$ \\
\hline
\end{tabular}




\subsection{Penerapan Metode TOPSIS}

Dalam penerapan metode TOPSIS, dilakukan tahapan-tahapan berikut.

1) Membuat Matriks Keputusan

Tabel 6. Matriks Nilai Keputusan Setiap Kriteria

\begin{tabular}{|c|c|c|c|c|c|c|}
\cline { 2 - 7 } \multicolumn{1}{c|}{} & cost/benefit & benefit & benefit & benefit & Benefit & cost \\
\cline { 2 - 7 } \multicolumn{1}{c|}{} & Bobot & 3 & 3 & 3 & 3 & 3 \\
\hline No & Alternatif/Kriteria & $\mathbf{C 1}$ & $\mathbf{C 2}$ & $\mathbf{C 3}$ & $\mathbf{C 4}$ & $\mathbf{C 5}$ \\
\hline 1 & P1 & 3 & 3 & 3 & 2 & 3 \\
\hline 2 & P2 & 3 & 3 & 4 & 3 & 2 \\
\hline 3 & P3 & 3 & 3 & 3 & 3 & 2 \\
\hline 4 & P4 & 3 & 3 & 2 & 3 & 1 \\
\hline 5 & P5 & 3 & 2 & 3 & 2 & 1 \\
\hline
\end{tabular}

2) Membuat Tabel Ternormalisasi

Setelah membuat matriks keputusan maka selanjutnya mencari nilai pembagi untuk menentukan matriks ternormalisasi. Dalam mencari pembagi dapat dilakukan dengan perhitungan :

Pembagi $\mathrm{C} 1=\sqrt{3^{2}+3^{2}+3^{2}+3^{2}+3^{2}}=6,708203932$

Tabel 7. Menentukan Nilai Pembagi Setiap Kriteria

\begin{tabular}{|c|l|c|c|c|c|c|}
\cline { 2 - 7 } \multicolumn{1}{c|}{} & cost/benefit & Benefit & Benefit & Benefit & benefit & cost \\
\cline { 2 - 7 } \multicolumn{1}{c|}{} & Kepentingan & 3 & 3 & 3 & 3 & 3 \\
\hline No & Alternatif/Kriteria & $\mathbf{C 1}$ & $\mathbf{C 2}$ & $\mathbf{C 3}$ & $\mathbf{C 4}$ & $\mathbf{C 5}$ \\
\hline 1 & P1 & 3 & 3 & 3 & 2 & 3 \\
\hline 2 & P2 & 3 & 3 & 4 & 3 & 2 \\
\hline 3 & P3 & 3 & 3 & 3 & 3 & 2 \\
\hline 4 & P4 & 3 & 3 & 2 & 3 & 1 \\
\hline 5 & P5 & 3 & 2 & 3 & 2 & 1 \\
\hline
\end{tabular}

Tabel 8. Matriks Ternormalisasi Setiap Kriteria

\begin{tabular}{|l|c|c|c|c|c|}
\hline cost/benefit & Benefit & Benefit & Benefit & benefit & cost \\
\hline Kepentingan & 3 & 3 & 3 & 3 & 3 \\
\hline Alternatif/Kriteria & $\mathbf{C 1}$ & $\mathbf{C 2}$ & $\mathbf{C 3}$ & $\mathbf{C 4}$ & C5 \\
\hline P1 & 0,447213595 & 0,474341649 & 0,437594974 & 0,338061702 & 0,688247202 \\
\hline P2 & 0,447213595 & 0,474341649 & 0,583459966 & 0,507092553 & 0,458831468 \\
\hline P3 & 0,447213595 & 0,474341649 & 0,437594974 & 0,507092553 & 0,458831468 \\
\hline P4 & 0,447213595 & 0,474341649 & 0,291729983 & 0,507092553 & 0,229415734 \\
\hline P5 & 0,447213595 & 0,316227766 & 0,437594974 & 0,338061702 & 0,229415734 \\
\hline
\end{tabular}

3) Membuat Matriks Normalisasi Berbobot

Pada langkah ini yang dilakukan adalah mengalikan setiap nilai matriks ternormalisasi dengan bobot kepentingan (W).

Tabel 9. Matriks Normalisasi Berbobot

\begin{tabular}{|l|c|c|c|c|c|}
\hline Alternatif/Kriteria & C1 & C2 & C3 & C4 & C5 \\
\hline P1 & 1.341640786 & 1.423024947 & 1.312784923 & 1.014185106 & 2.064741605 \\
\hline P2 & 1.341640786 & 1.423024947 & 1.750379898 & 1.521277659 & 1.376494403 \\
\hline P3 & 1.341640786 & 1.423024947 & 1.312784923 & 1.521277659 & 1.376494403 \\
\hline P4 & 1.341640786 & 1.423024947 & 0.875189949 & 1.521277659 & 0.688247202 \\
\hline P5 & 1.341640786 & 0.948683298 & 1.312784923 & 1.014185106 & 0.688247202 \\
\hline
\end{tabular}


4) Mencari Nilai Max dan Min

Nilai max adalah nilai tertinggi dari setiap kriteria pada matriks ternormalisasi berbobot, sedangkan nilai min adalah nilai terendah dari setiap kriteria pada matriks pada matriks berbobot.

Tabel 10. Nilai Tertinggi dan Terendah Setiap Kriteria

\begin{tabular}{|c|r|r|r|r|r|}
\hline $\mathbf{A}+$ & 1.341640786 & 1.423024947 & 1.750379898 & 1.521277659 & 0.688247202 \\
\hline $\mathbf{A}-$ & 1.341640786 & 0.948683298 & 0.875189949 & 1.014185106 & 2.064741605 \\
\hline
\end{tabular}

5) Mencari Nilai S+ dan S-

Nilai dari S+ dan S- digunakan untuk menentukan hasil yang akan diperoleh oleh alternatif. Dalam mencari nilai $\mathrm{S}+$ dan S- dapat dilakukan menggunakan perhitungan:

$$
\begin{aligned}
& S_{1}^{+}= \sqrt{(1,341640786-1,341640786)^{2}+(1.423024947-1.423024947)^{2}+(1.750379898-1.312784923)^{2}} \\
&+(1.521277659-1.014185106)^{2}+(0.688247202-2.064741605)^{2}=1.53080667 \\
& S_{1}^{-}= \sqrt{(1,341640786-1,341640786)^{2}+(0.948683298-1.423024947)^{2}+(0.875189949-1.312784923)^{2}+} \\
&(1.014185106-1.014185106)^{2}+(2.064741605-2.064741605)^{2}=0.64535987
\end{aligned}
$$

Tabel 11. Pengukuran Jarak Dari Alternatif ke Solusi Ideal

\begin{tabular}{|c|c|}
\hline S+ & S- \\
\hline 1.53080667 & 0.64535987 \\
\hline 0.688247202 & 1.312167868 \\
\hline 0.815581739 & 1.071128577 \\
\hline 0.875189949 & 1.541713235 \\
\hline 0.820751009 & 1.444377445 \\
\hline
\end{tabular}

6) Mencari Hasil (C)

Hasil merupakan nilai akhir dari setiap kriteria, berikut hasil dari setiap alternatif.

$$
C_{1}^{+}=\frac{0.64535987}{0.64535987+1.53080667}=0.296558126
$$

Tabel 12. Hasil Akhir Setiap Alternatif

\begin{tabular}{|c|c|c|}
\hline No Ranking & Alternatif & Hasil (C) \\
\hline 5 & P1 & 0.296558126 \\
\hline 1 & P2 & 0.655947802 \\
\hline 4 & P3 & 0.56772286 \\
\hline 2 & P4 & 0.637887875 \\
\hline 3 & P5 & 0.637658073 \\
\hline
\end{tabular}

\subsection{Penerapan Metode WP}

Dalam penerapan metode WP, dilakukan tahapan-tahapan berikut dengan nilai-nilai kategori dari setiap alternatif dalam bentuk tabel dan nilai yang sudah ditentukan.

1) Menentukan Normalisasi Alternatif

Tabel 13. Tabel Normalisasi Alternatif

\begin{tabular}{|c|c|c|c|c|c|c|}
\hline & cost/benefit & benefit & benefit & benefit & benefit & cost \\
\hline & Kepentingan & 3 & 3 & 3 & 3 & 3 \\
\hline No & Alternatif/Kriteria & $\mathbf{C 1}$ & $\mathbf{C 2}$ & $\mathbf{C 3}$ & $\mathbf{C 4}$ & $\mathbf{C 5}$ \\
\hline 1 & P1 & 3 & 3 & 3 & 2 & 3 \\
\hline 2 & P2 & 3 & 3 & 4 & 3 & 2 \\
\hline 3 & P3 & 3 & 3 & 3 & 3 & 2 \\
\hline 4 & P4 & 3 & 3 & 2 & 3 & 1 \\
\hline 5 & P5 & 3 & 2 & 3 & 2 & 1 \\
\hline
\end{tabular}


2) Menentukan Kriteria-Kriteria

Tabel 14

\begin{tabular}{|l|l|}
\hline \multicolumn{1}{|c|}{ Kriteria } & \multicolumn{1}{c|}{ Sifat } \\
\hline C1 = Rata-Rata Raport & $\begin{array}{l}\text { Benefit/menguntungkan } \\
\text { Alasan : semakin besar nilai rata-rata raport pada } \\
\text { alternatif, maka pengaruh untuk terpilih menjadi siswa } \\
\text { berprestasi semakin besar }\end{array}$ \\
\hline C2 = Kelakuan & $\begin{array}{l}\text { Benefit/menguntungkan } \\
\text { Alasan: semakin baik kelakuan dari alternatif akan } \\
\text { mempengaruhi nilai dari kepribadiannya }\end{array}$ \\
\hline C3 = Kedisiplinan & $\begin{array}{l}\text { Benefit/menguntungkan } \\
\text { Alasan: semakin tinggi disiplin belajar seorang siswa, } \\
\text { akan semakin tinggi prestasi belajar yang diperoleh }\end{array}$ \\
\hline C4 = Kerapian & $\begin{array}{l}\text { Benefit/menguntungkan } \\
\text { Alasan: karena salah satu indikator menjadi siswa yang } \\
\text { teladan. }\end{array}$ \\
\hline C5 = Absensi & $\begin{array}{l}\text { Cost/merugikan } \\
\text { Alasan: semakin kecil absensi dari alternatif akan } \\
\text { mempengaruhi prestasi siswa. }\end{array}$ \\
\hline
\end{tabular}

3) Menentukan Normalisasi Bobot

$\mathrm{W}=\begin{array}{ccccc}3 & 3 & 3 & 3 & 3\end{array}$

Maka perbaikan bobot yang dilakukan:

$\mathrm{W} 1=3 /(3+3+3+3+3)=3 / 11=0,2$

$\mathrm{W} 2=3 /(3+3+3+3+3)=3 / 11=0,2$

$\mathrm{W} 3=3 /(3+3+3+3+3)=3 / 11=0,2$

$\mathrm{W} 4=3 /(3+3+3+3+3)=3 / 11=0,2$

$\mathrm{W} 5=3 /(3+3+3+3+3)=3 / 11=0,2$

Jika nilai $\mathrm{W} 1+\mathrm{W} 2+\mathrm{W} 3+\mathrm{W} 4+\mathrm{W} 5$ dijumlahkan maka hasilnya $=1$

4) Menentukan Nilai Vektor $S$

Menentukan nilai vektor $\mathrm{S}$ dengan mengalikan seluruh kriteria bagi sebuah alternatif dengan bobot sebagai pangkat positif (+) untuk kriteria benefit dan bobot berfungsi sebagai pangkat negatif (-) pada kriteria cost.

$S_{1}=\left(3^{0,2}\right)\left(3^{0,2}\right)\left(3^{0,2}\right)\left(2^{0,2}\right)\left(3^{0,2}\right)=1.868985896$

Tabel 15. Nilai Preferensi Alternatif

\begin{tabular}{|l|l|}
\hline S1 & 1.782602458 \\
\hline S2 & 2.220643035 \\
\hline S3 & 2.096481356 \\
\hline S4 & 2.220643035 \\
\hline S5 & 2.047672511 \\
\hline
\end{tabular}

5) Menentukan Nilai Vektor V

$$
\begin{aligned}
V_{1} & =\frac{1.782602458}{(1.782602458+2.220643035+2.096481356+2.220643035+2.047672511)} \\
& =0.171932404
\end{aligned}
$$

Tabel 16. Nilai Untuk Perankingan

\begin{tabular}{|c|c|}
\hline V1 & 0.171932404 \\
\hline V2 & 0.214181516 \\
\hline V3 & 0.202206094 \\
\hline V4 & 0.214181516 \\
\hline V5 & 0.19749847 \\
\hline
\end{tabular}


6) Merangking Nilai Vektor V

Dengan melihat point pada langkah ke-5, didapatkan kesimpulan bahwa nilai V2 lebih besar dari V yang lain.

Tabel 17. Hasil Perankingan

\begin{tabular}{|c|c|c|}
\hline Rangking & Alternatif & Nilai vektor V \\
\hline 5 & P1 & 0.171932404 \\
\hline 1 & P2 & 0.214181516 \\
\hline 3 & P3 & 0.202206094 \\
\hline 2 & P4 & 0.214181515 \\
\hline 4 & P5 & 0.19749847 \\
\hline
\end{tabular}

\subsection{Hasil Perankingan Perhitungan Kedua Metode}

Tabel 18. Hasil Perangkingan Menggunakan Metode TOPSIS

\begin{tabular}{|c|c|c|}
\hline Ranking & Alternatif & Hasil (C) \\
\hline 5 & P1 & 0.296558126 \\
\hline 1 & P2 & 0.655947802 \\
\hline 4 & P3 & 0.56772286 \\
\hline 2 & P4 & 0.637887875 \\
\hline 3 & P5 & 0.637658073 \\
\hline
\end{tabular}

Tabel 19. Hasil Perangkingan Menggunakan Metode WP

\begin{tabular}{|c|c|c|}
\hline Rangking & Alternatif & Nilai vektor V \\
\hline 5 & P1 & 0.171932404 \\
\hline 1 & P2 & 0.214181516 \\
\hline 3 & P3 & 0.202206094 \\
\hline 2 & P4 & 0.214181515 \\
\hline 4 & P5 & 0.19749847 \\
\hline
\end{tabular}

Tabel 20. Tabulasi Kinerja Metode TOPSIS dan WP

\begin{tabular}{|c|c|c|c|c|c|}
\hline \multirow{2}{*}{ Metode } & \multicolumn{5}{|c|}{ Alternatif } \\
\cline { 2 - 6 } & P1 & P2 & P3 & P4 & P5 \\
\hline TOPSIS & 0.296558126 & 0.655947802 & 0,56772286 & 0,637887875 & 0,637658073 \\
\hline WP & 0.171932404 & 0.214181516 & 0.202206094 & 0.214181515 & 0.19749847 \\
\hline
\end{tabular}

Grafik penilaian dari metode TOPSIS dan WP ditunjukkan pada gambar di bawah ini.

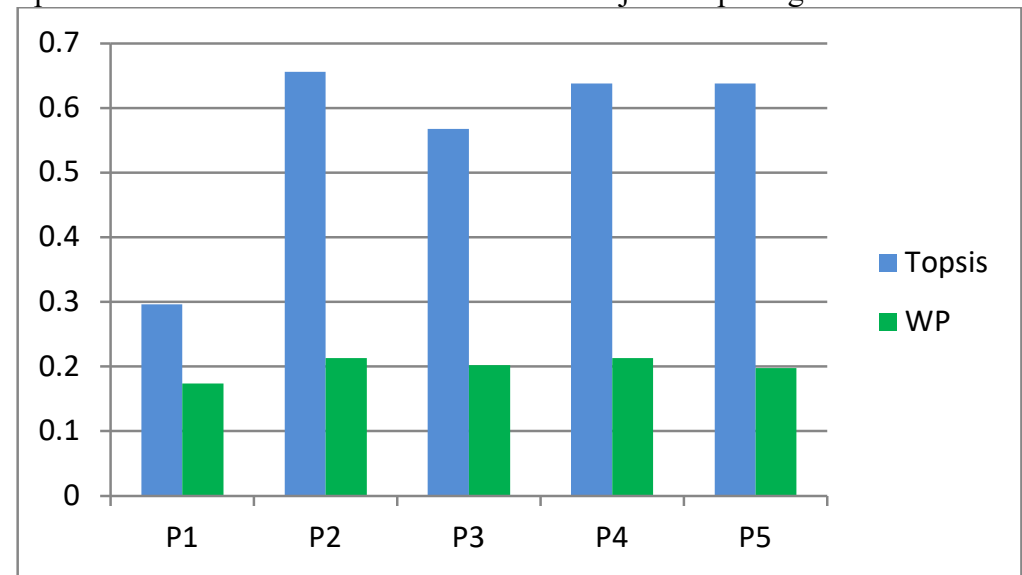

Gambar 2. Grafik Penilaian Metode TOPSIS dan WP

Dari gambar grafik di atas nilai TOPSIS berwarna biru menunjukkan nilai terbesar yaitu P2 dengan nilai 0.655947802 dibanding dengan nilai WP berwarna hijau yaitu P2 denga nilai 0.214181516 . 


\subsection{Perhitungan Akurasi TOPSIS dan WP}

Hasil perankingan TOPSIS dan WP dibandingkan dengan hasil faktual berdasarkan seleksi oleh tim dari MTs Al-Ishlah. Tabel perbandingannya dapat dilihat pada tabel berikut.

Tabel 21. Perbandingan Perankingan Data Faktual, TOPSIS, dan WP

\begin{tabular}{|c|c|c|}
\hline Data Faktual & Topsis & WP \\
\hline P2 & P2 & P2 \\
\hline P3 & P4 & P4 \\
\hline P5 & P5 & P3 \\
\hline P4 & P3 & P5 \\
\hline P1 & P1 & P1 \\
\hline
\end{tabular}

Dari tabel perbandingan tersebut, kedua metode yang berwarna abu-abu menunjukkan pengurutan nilai yang salah atau ketidaksesuaian dengan data faktual, sehingga proses perhitungan tingkat akurasinya adalah:

Akurasi Metode TOPSIS:

Akurasi $=3 / 5 \times 100 \%=60 \%$

\section{$\underline{\text { Akurasi Metode Weighted Product (WP) }}$}

Akurasi $=4 / 5 \times 100 \%=80 \%$

Berdasarkan sample data yang diproses tersebut, tingkat akurasi metode WP lebih baik dibandingkan tingkat akurasi metode TOPSIS. Selanjutnya metode TOPSIS dan WP ini dituangkan menjadi sebuah sistem perangkat lunak yang dibahas pada bab 3 yang kemudian dilakukan pengujian terhadap 200 data.

\section{HASIL DAN ANALISIS}

\subsection{Implementasi Metode TOPSIS dan WP ke Dalam Perangkat Lunak}

Pada tahap ini, metode TOPSI dan WP diterapkan ke dalam perangkat lunak yang mana perangkat lunak tersebut sebagai alat untuk pengujian. Berikut screenshot halaman aplikasi perangkat lunak yang telah dibuat.

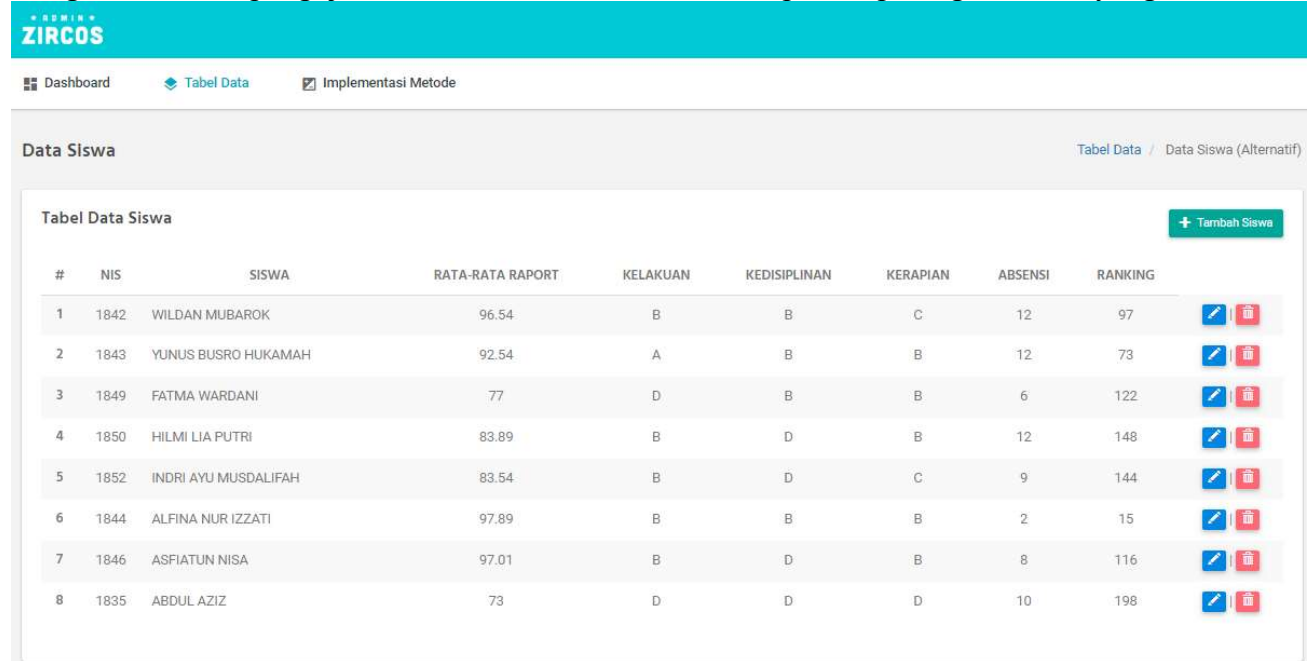

Gambar 3. Screenshot Perangkat Lunak Halaman Data Siswa 


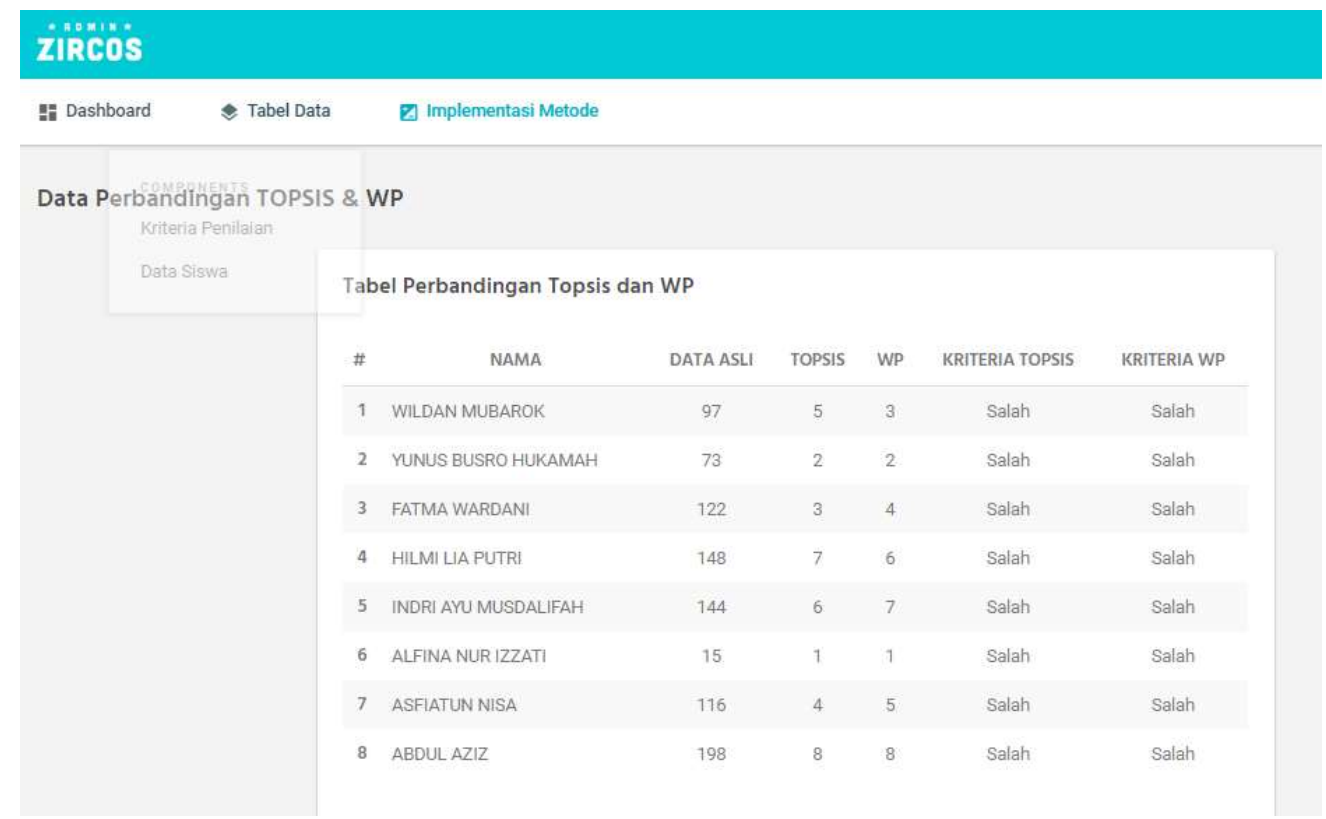

Gambar 4. Screenshot Perangkat Lunak Halaman Perbandingan TOPSIS dan WP

\subsection{Pengujian}

Pengujian sistem dilakukan pada 200 data siswa yang diproses dengan metode TOPSIS maupun WP. Pada hasil pengujian metode TOPSIS dan WP pada 200 data siswa menghasilkan jumlah urutan akurasi pada kedua metode yaitu pada metode Topsis adalah 168 data sedangkan pada metode WP adalah 178 data.

Setelah pengujian dilakukan menggunakan sistem perangkat lunak tersebut, selanjutnya menghitung tingkat akurasi metode TOPSIS dan metode WP pada studi kasus penentuan siswa berprestasi di MTs Al-Ishlah. Rumus perhitungan tingkat akurasinya menggunakan rumus berikut:

$$
\begin{array}{ll}
\text { Akurasi }=\frac{\boldsymbol{X}}{\boldsymbol{N}} \boldsymbol{x} \mathbf{1 0 0} \% & \\
\text { Dimana : } & \mathrm{N}=\text { banyaknya data } \\
\mathrm{X} & =\text { banyaknya data yang benar }
\end{array}
$$

Sehingga perhitungan akurasi pada perbandingan metode TOPSIS dan metode WP dapat digambarkan dengan perhitungan berikut:

$\begin{array}{ll}\text { Diketahui: } & \\ \mathrm{N} & =200 \text { data } \\ X_{\text {Topsis }} & =168 \text { data } \\ X_{W P} & =178 \text { data }\end{array}$

Maka,

Akurasi TOPSIS

Akurasi WP

$$
\begin{aligned}
& =\frac{168}{200} \times 100 \%=84 \% \\
& =\frac{178}{200} \times 100 \%=87,5 \%
\end{aligned}
$$

Setelah dilakukan perbandingan dan dianalisis, didapatkan hasil akurasi dari kedua metode, yaitu pada metode TOPSIS adalah 84\%, sedangkan pada metode WP didapatkan nilai akurasi 87,5\%. Dengan demikian, pada studi kasus penentuan siswa berprestasi di MTs Al-Ishlah dengan pengujian terhadap 200 data siswa, maka dapat dikatakan bahwa metode WP lebih akurat dibandingkan metode TOPSIS.

\section{KESIMPULAN}

Berdasarkan hasil penelitian dan analisa yang telah dilaksanakan, maka dapat disimpulkan bahwa:

1) Metode TOPSIS dan WP merupakan metode untuk pengambilan keputusan dengan multikriteria, sehingga sangat cocok digunakan untuk penentuan siswa berprestasi.

2) Metode TOPSIS dan WP ini memiliki tingkat akurasi yang tinggi untuk menentukan siswa berprestasi, karena sama-sama menghasilkan tingkat akurasi $>80 \%$.

3) Berdasarkan hasil perbandingan tingkat akurasi dari kedua metode tersebut (TOPSIS dan WP) didapatkan bahwa metode TOPSIS memiliki nilai akurasi 84\%, sedangkan tingkat akurasi pada metode WP sebesar 
87.5\%. Dengan demikian, pada studi kasus penentuan siswa berprestasi di MTs Al-Ishlah dengan pengujian terhadap 200 data siswa, maka dapat dikatakan bahwa metode WP lebih akurat dibandingkan metode TOPSIS.

\section{REFERENSI}

[1] Asmara, Pembelajaran yang Efektif. Jakarta: Renika Cipta, 2009.

[2] Harjati, Psikologi Belajar. Jakarta: PT. Rineka Cipta, 2008.

[3] Kusumadewi, Fuzzy Multi-Attribute Decision Making (Fuzzy MADM). Yogyakarta: Graha Ilmu, 2006.

[4] V. Gayatri and M. Chetan, "Comparative Study of Different Multi-criteria Decision-Making Methods," Int. J. Adv. Comput. Theory Eng., vol. 2, no. 4, pp. 2319 - 2526, 2013. 